\title{
MORAVSKOSLEZSKÝ KRAJ - REGION S KLESAJÍCÍM POČTEM OBYVATEL ${ }^{1}$
}

\section{Pavel Tuleja, Karin Gajdová}

\section{Klíčová slova:}

Moravskoslezský kraj, obyvatelstvo, přirozený přírůstek, prrírůstek stěhováním, přistěhovalí, úhrnná plodnost, vystěhovalí

\section{Key words:}

Moravian-Silesian Region, population, natural increase, net migration, immigrants, total fertility, emigrants

\begin{abstract}
Abstrakt
V rámci České republiky nalezneme regiony, jejichž demografický vývoj byl poměrně negativně ovlivněn intenzivními socioekonomickými změnami, jimiž celá Česká republika prošla v průběhu 90. let minulého století. Mezi tyto územně správní celky patř́ také Moravskoslezský kraj, jehož demografický vývoj je charakterizován dlouhodobým poklesem počtu obyvatel. Příčiny poklesu počtu obyvatel jsme nalezli jak v oblasti přirozeného přírůstku, tak v oblasti prrírůstku stěhováním, ovšem jako závažnější problém se jeví záporné migrační saldo. V tomto př́padě je dlouhodobý vývoj v kraji v rozporu s vývojem v ostatních krajích České republiky.
\end{abstract}

\begin{abstract}
In the Czech Republic, finding regions whose demographics were quite negatively affected by the intense socio-economic change, which went through the whole Czech Republic during the 90th the last century. These administrative units include the Moravian-Silesian region, the demographic development is characterized by long-term population decline. Although the causes of population decline was found in both natural increase and net migration in the area, as more serious problem appears to us a negative migration balance, as in this case, the longterm development in the region, contrary to developments in other regions of the Czech Republic.
\end{abstract}

\section{Úvod}

V průběhu 90. let minulého století prošla Česká republika řadou poměrně intenzivních socioekonomických změn, které se následně odrazily také v jejím demografickém vývoji. Ačkoliv intenzita těchto změn byla ve všech regionech podstatně stejná, nalezneme v rámci České republiky jak kraje, v jejichž případě výše uvedené změny ovlivnily demografický vývoj daného regionu vesměs pozitivně, tak regiony, kde tyto změny působily na vývoj počtu obyvatel spíše negativně. Mezi tyto územně správní celky můžeme zařadit také Moravskoslezský kraj, který je charakteristický dlouhodobým poklesem počtu obyvatel. Tento negativní trend vývoje se zejména v posledních třech letech začíná jevit jako velmi závažný. Vzhledem k tomu, že demografický vývoj je zpravidla úzce spojen s vývojem na trhu práce a ovlivňuje tak do značné míry vlastní podnikatelské prostředí regionu, jeví se nám analýza dané problematiky jako velmi zajímavá a navýsost potřebná.

\footnotetext{
${ }^{1}$ Tento článek vznikl v rámci Studentské grantové soutěže, projektu SGS/7/2012: „,Vliv regionálních disparit na podnikatelské prostředi”.
} 
Vzhledem k tomu, že jedním z regionů, který se jeví jako vhodný pro analýzu vlivu disparit na podnikatelské prostředí je Moravskoslezský kraj, zaměřili jsme se v rámci této stati právě na tento region. Námi provedená analýza bude sloužit jako východisko nejen následné analýzy vývoje na regionálním trhu práce, ale také pro zhodnocení vlivu zjištěných rozdílností na podnikatelské prostředí kraje.

\section{Demografický vývoj a struktura obyvatel Moravskoslezského kraje}

Podle předběžných údajů, žilo k 31. 12. 2011 v Moravskoslezském kraji 1 230,5 tis. osob, což je z historického hlediska nejnižší počet obyvatel, jenž byl na daném území zaregistrován k poslednímu dni př́slušného roku. Oproti předchozímu roku pak poklesl počet obyvatel poměrně dramaticky, a to o 12,7 tis. osob, což potvrzuje dlouhodobý trend poklesu stavu obyvatelstva. Jeho výše se mezi roky 1991 a 2011 snížila o 50,5 tis. osob. Budeme-li hledat př́íciny tohoto vývoje, pak v obecné rovině dospějeme k závěru, že Moravskoslezský kraj do jisté míry kopíruje základní rysy, které se v chování obyvatel celé České republiky začaly objevovat na přelomu století. Za nejmarkantnější projevy tohoto vývoje pak ve shodě $s$ Mulíčkem (Kolektiv autorů, 2006, s. 10), považujeme:

- výrazný pokles porodnosti, když mezi roky 1993 a 2011 v kraji postupně klesal počet živě narozených dětí, o čemž svědčí také hodnota podílu tohoto ukazatele na 1000 obyvatel kraje, která postupně klesla z původní hodnoty 12,4 \%, na konečnou hodnotu 9,6\%o,

- faktickou stabilizaci vývoje počtu zemřelých, když podíl této skupiny v námi analyzovaném období vzrostl pouze o 0,4 promile, tj. z původních 10,5 \%o na konečných 10,9\%.

- pokles počtu uzavřených manželství a současně také určitá stagnace rozvodovosti, což opět můžeme podložit statistickými údaji, které hovoří o tom, že hodnota ukazatele, jenž vyjadřuje podíl sňatků na 1.000 obyvatel Moravskoslezského kraje, poklesla mezi roky 1993 a 2011 z původních 6,3 \%o na konečných 4,2 \%o, tj. v absolutních hodnotách ročně o 3.107 sňatků, kdežto podíl rozvodů na jeden tisíc obyvatel dlouhodobě setrvával na víceméně stabilní úrovni $2,8 \%$.

- a v neposlední řadě také zastavení procesu územní koncentrace obyvatelstva, o čemž, dle našeho názoru, svědčí zejména výrazný odliv obyvatel z oblasti ostravskokarvinské aglomerace, což podtrhují také statistická dat, z nichž vyplývá, že v letech 2000-2011 dosahoval v okresech Ostrava-město a Karviná průměrný roční přírůstek obyvatel stěhováním hodnoty -1 662 osob, přičemž průměrná hodnota tohoto ukazatele za celý Moravskoslezský kraj nabývala výše -1 651 osob.

Tabulka 1: Počet obyvatel Moravskoslezského kraje podle okresů v letech 2000 a 2011 (stav k 31. 12. př́íslušného roku)

\begin{tabular}{|l|r|r|r|r|r|r|}
\hline & \multicolumn{2}{|c|}{ počet obyvatel } & \multicolumn{2}{c|}{ podíl na počtu obyv. kraje } & \multicolumn{2}{c|}{ př́růstek/úbytek } \\
\hline & 2000 & 2011 & 2000 & \multicolumn{1}{c|}{2011} & \multicolumn{1}{c|}{ absolutní } & \multicolumn{1}{c|}{ relativní } \\
\hline Bruntál & 100598 & 96335 & $7,90 \%$ & $7,83 \%$ & -4263 & $-4,24 \%$ \\
\hline Frýdek-Místek & 210638 & 211835 & $16,54 \%$ & $17,21 \%$ & 1197 & $0,57 \%$ \\
\hline Karviná & 283317 & 263039 & $22,25 \%$ & $21,38 \%$ & -20278 & $-7,16 \%$ \\
\hline Nový Jičín & 154006 & 152221 & $12,09 \%$ & $12,37 \%$ & -1785 & $-1,16 \%$ \\
\hline Opava & 177940 & 177158 & $13,97 \%$ & $14,40 \%$ & -782 & $-0,44 \%$ \\
\hline Ostrava & 347038 & 329946 & $27,25 \%$ & $26,81 \%$ & -17092 & $-4,93 \%$ \\
\hline
\end{tabular}

Zdroj: Český statistický úřad a vlastní výpočet na základě dat ČSÚ 
Ačkoliv se výše uvedený pokles počtu obyvatel jeví jako poměrně výrazný, Moravskoslezský kraj i nadále patří mezi tři nejlidnatější regiony České republiky, když jej v posledních třech letech námi sledovaného období předstihly pouze Hlavní město Praha s 1 241,3 tis. osobami a Středočeský kraj s 1279,1 tis. obyvateli.

Podíváme-li se na vývoj počtu obyvatel Moravskoslezského kraje z pohledu jednotlivých okresů (viz tabulka 1), pak dospějeme k závěru, že okresem s největším počtem obyvatel v kraji je dlouhodobě okres Ostrava, jenž se v roce 2011 s necelými 330 tis. obyvateli podílel na celkovém počtu obyvatel kraje $26,81 \%$. Za okres s nejmenším počtem obyvatel můžeme naopak označit okres Bruntál, jehož podíl na celkovém počtu obyvatel v Moravskoslezském kraji dosahoval hodnoty $7,83 \%$. Jak je z tabulky 1 zřejmé, pro Moravskoslezský kraj je charakteristický dlouhodobý pokles počtu obyvatel, což se v námi analyzovaném období nejvýrazněji projevilo v okrese Karviná, kde v prvních jedenácti letech nového tisíciletí poklesl počet obyvatel o 7,16 \%, což v absolutním vyjádření značí úbytek přesahující 20 tis. osob. Dále pak v okresech Ostrava a Bruntál, kde jsme zaznamenali relativní úbytek obyvatel přesahující čtyři procentní body $(-4,93 \%$ v okrese Ostrava a $-4,24 \%$ v okrese Bruntál), což v absolutních hodnotách značí propad o 17,1, resp. 4,3 tis. osob. Jediným okresem Moravskoslezského kraje, který se v letech 2000 až 2011 vyznačoval prrírůstkem počtu obyvatel tak byl okres Frýdek-Místek, v jehož případě vzrostl nejen počet obyvatel žijících na území okresu o 0,57 p. b., což v absolutní vyjádření značí přírůstek o 1,2 tis. osob, ale také jeho podíl na celkovém počtu obyvatel v kraji, který z původních 16,54 \% vzrostl na konečných $17,21 \%$.

\section{Graf 1: Vývoj průměrného věku obyvatel vokresech Moravskoslezského kraje, Moravskoslezském kraji a České republice mezi roky 2000 a 2010}

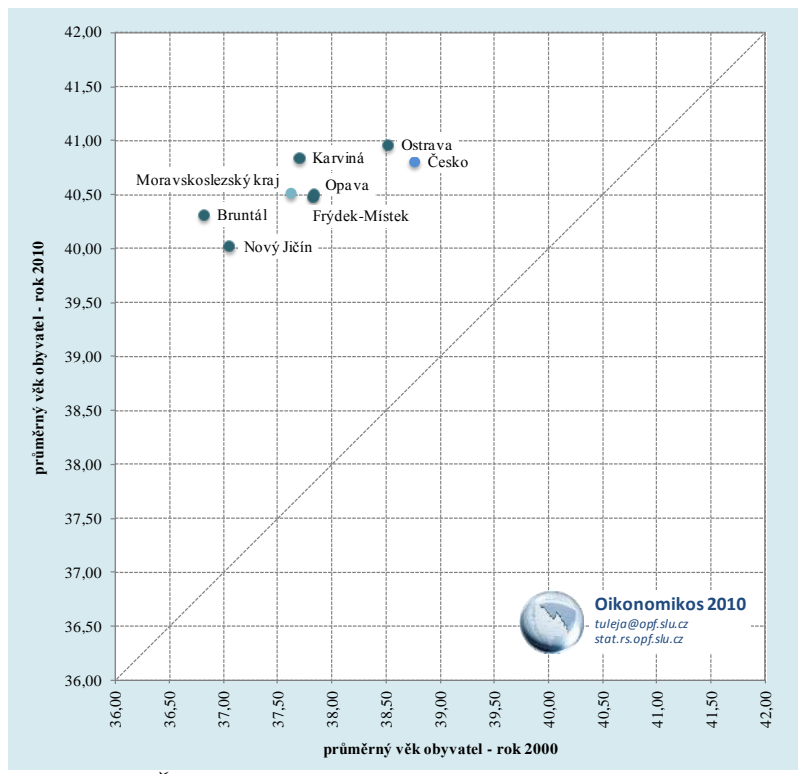

Zdroj: Vlastní výpočet na základě dat Českého statistického úřadu

Vzhledem k tomu, že Moravskoslezský kraj je krajem, v němž mezi roky 2000 a 2011 poklesl počet obyvatel o 43 tis., vyvstává před námi otázka, jak se tento vývoj podepsal na průměrném věku osob trvale žijících na jeho území. Jak je patrné z grafu 1, v roce 2010 se průměrný věk obyvatel Moravskoslezského kraje pohyboval na úrovni 40,52 let, což je hodnota, která je o 0,28 menší, než je hodnota průměrného věku obyvatel České republiky. Dá se tedy říci, že společně s poklesem počtu obyvatel roste také jeho průměrný věk, přičemž dynamika růstu tohoto ukazatele je poněkud vyšší, než je tomu v př́padě České republiky 
jako celku. Zatímco v Česku vzrostl v námi analyzovaném období průměrný věk obyvatel o 2,05 roku, v prŕípadě MS-kraje hodnota tohoto ukazatele vzrostla o 2,90 roku. V př́padě jednotlivých okresů pak můžeme nejvýraznější růst průměrného věku obyvatel zaznamenat $u$ obyvatel okresů Bruntál, Karviná a Nový Jičín, v nichž hodnota tohoto ukazatele v průběhu jedenácti let vzrostla o 3,51, 3,15 a 2,97 roku. I přes výše uvedený nárůst okresy Nový Jičín a Bruntál zůstávají oblastmi s nejnižším průměrným věkem svých obyvatel. V př́padě okresu Nový Jičín dosahoval v roce 2010 průměrný věk obyvatel hodnoty 40,02 let a u okresu Bruntál to bylo 40,32 let. Okresem s nejvyšším průměrným věkem pak byl v průběhu celého námi analyzovaného období okres Ostrava, kde se v posledním roce námi analyzovaného období průměrných věk obyvatel pohyboval na úrovni 40,97 let, což je hodnota, která o 0,16 roku překračuje i celorepublikový průměr. Jak je z výše uvedeného textu i grafu 1 zřejmé, v první dekádě 21. století se hodnota průměrného věku ve všech okresech Moravskoslezského kraje výrazně zvýšila, přičemž tento růst je u všech okresů vyšší, než v případě České republiky jako celku.

Porovnáme-li demografický vývoj v Moravskoslezském kraji s demografickým vývojem v České republice, pak dospějeme $\mathrm{k}$ závěru, že z celorepublikového hlediska patří k př́ičinám stárnutí populace klesající porodnost a prodlužování délky života. Vyjdeme-li z údajů zachycených v grafu 2, pak zde dospíváme k závěru, že s největším poklesem podílu věkové kategorie na celkovém počtu obyvatel se setkáváme u osob ve věku 10 až 14 let, kde v prrípadě obyvatel mužského pohlaví došlo k propadu o $2,08 \mathrm{p}$. b. a u obyvatel ženského pohlaví o 1,85 \% a u obyvatel spadajících do věkové kategorie 20-24 let v jejichž př́padě dosahovaly poklesy hodnoty 1,83 a $1,64 \%$. Tyto dvě kategorie pak byly doplněny věkovou kategorií 50 až 54 let, v jejímž př́ípadě se podíl mužů snížil o 1,52 a podíl žen o 1,56 \%. Také $\mathrm{v}$ tomto případě pak můžeme zaznamenat pokles podílu mladé generace na celkovém počtu obyvatel, a to o $12,06 \%$, což je číslo, jenž je jen nepatrně nižší, než tomu bylo v př́padě Moravskoslezského kraje. Z hlediska růstu podílu pak z celorepublikového pohledu hrála největší roli věková kategorie 60-64 let (2,44 a 2,48 \%) a dále pak věkové kategorie 30-34 let $(1,87$ a 1,69 \%) a 35-39 let (1,80 a 1,63 \%). Nejstarší věkové kategorie, jež v našem pojetí zahrnují obyvatele starší 55 let, pak v daném období zaznamenaly růst podílu o 10,25 p. b., což byl údaj, jenž je o 1,75 p. b. nižší, než je tomu v případě Moravskoslezského kraje, z čehož by se dalo usuzovat, že mezi roky 2000 až 2010 o něco více v Česku posílila věková kategorie 30-54 let.

\section{Graf 2: Srovnání věkové struktury obyvatel Moravskoslezského kraje a České republiky $v$ roce 2010}

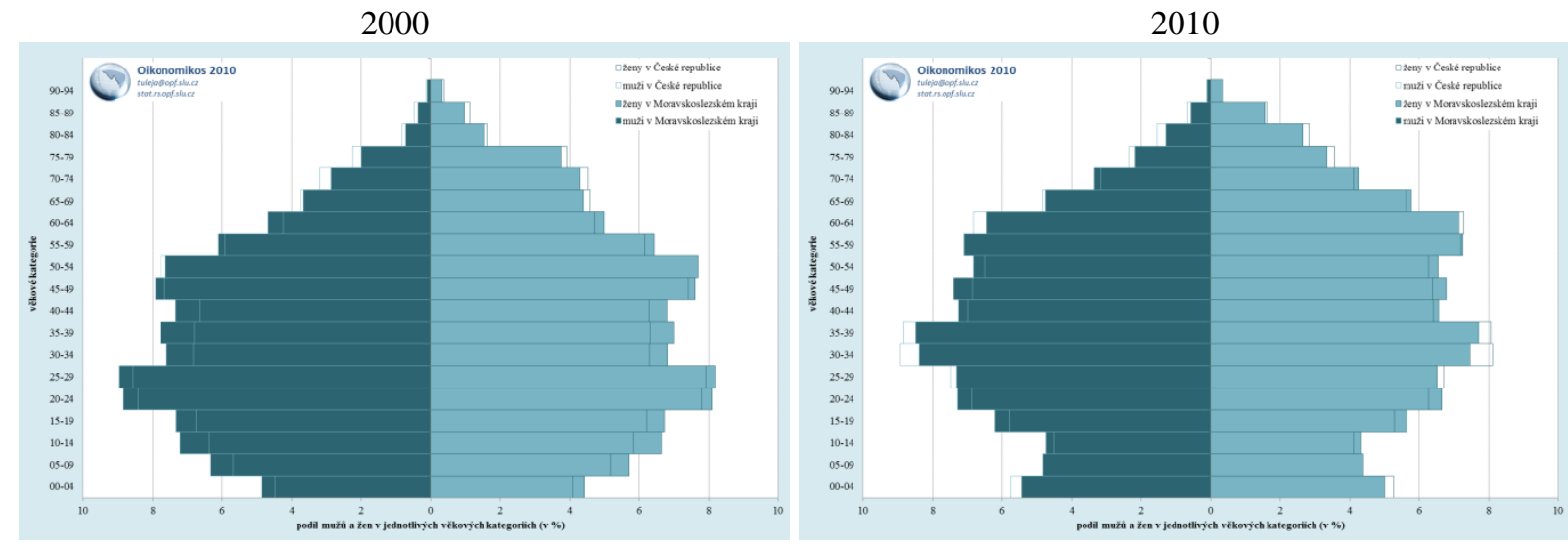

Zdroj: Vlastní zpracování na základě dat Českého statistického úřadu 


\section{Přirozený př́rírstek obyvatel Moravskoslezského kraje}

Změna v demografickém chování, kterou můžeme v Moravskoslezském kraji, podobně jako v celé České republice, zaznamenat v poslední dekádě minulého století, bývá často přirovnávána $\mathrm{k}$ druhému demografickému přechodu, jenž $\mathrm{v}$ západoevropských zemích započal na přelomu 70. a 80. let minulého století. Jak uvádí (Žák a kol., 2002, s. 184), druhá demografická revoluce se $\mathrm{v}$ zemích západní Evropy projevila ...výrazným poklesem plodnosti až pod záchovnou úroveň (zdá se, že úhrnná plodnost se stabilizuje někde na úrovni 1,7, tj. asi 1,7 ditěte připadající na jednu ženu během života), snižením úmrtnosti zejména starých osob (střední délka života di̊chodců se prodloužila zhruba o $20 \%$ ) a intenzivní mezistátní migrací (prírůstek migraci je pro zachováni velikosti populace podstatný). To znamená, že tyto populace rychle stárnou a potenciálně vymíraji a zároven̆ se potýkaji s problémy, které přinásí imigrace. Tento demografický přechod pak dle F. Koschina (2007) úzce souvisí se ...znalostní revolucí a se strukturálními, kulturními a technologickými změnami, které přináši (vznik nové kategorie znalostni pracovník, posilení úlohy vzdělání, princip rovnosti ve všech oblastech [přístup ke vzdělání, emancipace žen, rozvoj demokracie], informační a komunikační technologie), což jsou faktory, které od počátku 90. let poměrně výrazně ovlivňují také demografický vývoj nejen v celé České republice, ale také v Moravskoslezském kraji.

Vyjdeme-li z dostupných statistických údajů, pak zjistíme, že v poslední dekádě minulého století prošel Moravskoslezský kraj obdobím výrazného poklesu intenzity plodnosti, když počet živě narozených dětí, připadající na jednu ženu poklesl z hodnoty 1,68 v roce 1993 na hodnotu 1,13 v roce 2000. Hodnota úhrnné plodnosti tak v Moravskoslezském kraji v průběhu osmi let poklesla o 0,55 dítěte na jednu ženu, díky čemuž se tento kraj v rámci České republiky na počátku nového tisíciletí nacházel na desátém místě pomyslného žebříčku. Nižší úhrnné plodnosti dosahovaly pouze kraje Zlínský (1,13), Jihomoravský $(1,10)$, Olomoucký $(1,10)$ a Hl. m. Praha $(1,07)$. Toto období poklesu bylo následně vystřídáno obdobím zintenzivnění plodnosti, jež vyvrcholilo v roce 2007, kdy počet živě narozených dětí na jednu ženu v průběhu jejího reprodukčního období vzrostl z 1,32 na 1,44 dítěte. Poslední dva roky, pro něž máme k dispozici statistická data, pak můžeme označit za roky stagnace úhrnné plodnosti. V průběhu posledních osmnácti let se tak Moravskoslezský kraj zařadil mezi pětici krajů s nejnižší úrovní úhrnné plodnosti v České republice.

Vývoj úhrnné plodnosti se zásadním způsobem podepsal na vývoji přirozeného prŕrůstku obyvatelstva, jehož vývoj byl ovlivněn především poměrně rychlými změnami porodnosti a relativně malými změnami intenzity úmrtnosti, o čemž svědčí také údaje zachycené v grafu 3. Vyjdeme-li z těchto údajů, pak dospějeme k závěru, z nějž vyplývá, že od roku 1991do roku 2000 byl pro Moravskoslezský kraj charakteristický poměrně intenzivní pokles míry natality, která se z původní hodnoty 13,50 \% snížila na doposavad nejnižší dosaženou hodnotu 8,83 \%o, což znamená, že v průběhu deseti let poklesl v kraji počet živě narozených dětí na jeden tisíc obyvatel o téměř pět osob. Podobně jako u úhrnné plodnosti, také v př́ípadě míry natality můžeme na počátku nového tisíciletí zaznamenat nárůst hodnoty tohoto ukazatele, přičemž největší intenzity růstu dosáhla hrubá míra porodnosti mezi roky 2006 a 2007, kdy vzrostla o $0,79 \%$. Naopak s nejvýraznějším poklesem počtu živě narozených dětí na jeden tisíc obyvatel se můžeme setkat v posledním roce námi analyzovaného období, kdy se hodnota tohoto ukazatele snížila o $0,94 \%$, tj. o téměř jedno dítě na tisíc obyvatel. 
Tabulka 2: Úhrnná plodnost $\mathrm{v}$ České republice a $\mathrm{v}$ Moravskoslezském kraji v letech $2000-2010$

\begin{tabular}{|l|c|c|c|c|c|c|c|c|c|c|c|}
\hline & 2000 & 2001 & 2002 & 2003 & 2004 & 2005 & 2006 & 2007 & 2008 & 2009 & 2010 \\
\hline Česko & 1,144 & 1,146 & 1,171 & 1,179 & 1,226 & 1,282 & 1,328 & 1,438 & 1,497 & 1,492 & 1,493 \\
\hline MS-kraj & 1,128 & 1,159 & 1,176 & 1,196 & 1,233 & 1,284 & 1,319 & 1,440 & 1,463 & 1,468 & 1,474 \\
\hline
\end{tabular}

Zdroj: data z Českého statistického úřadu

\section{Graf 3: Vývoj měr natality a mortality v Moravskoslezském kraji v letech 1991-2011}

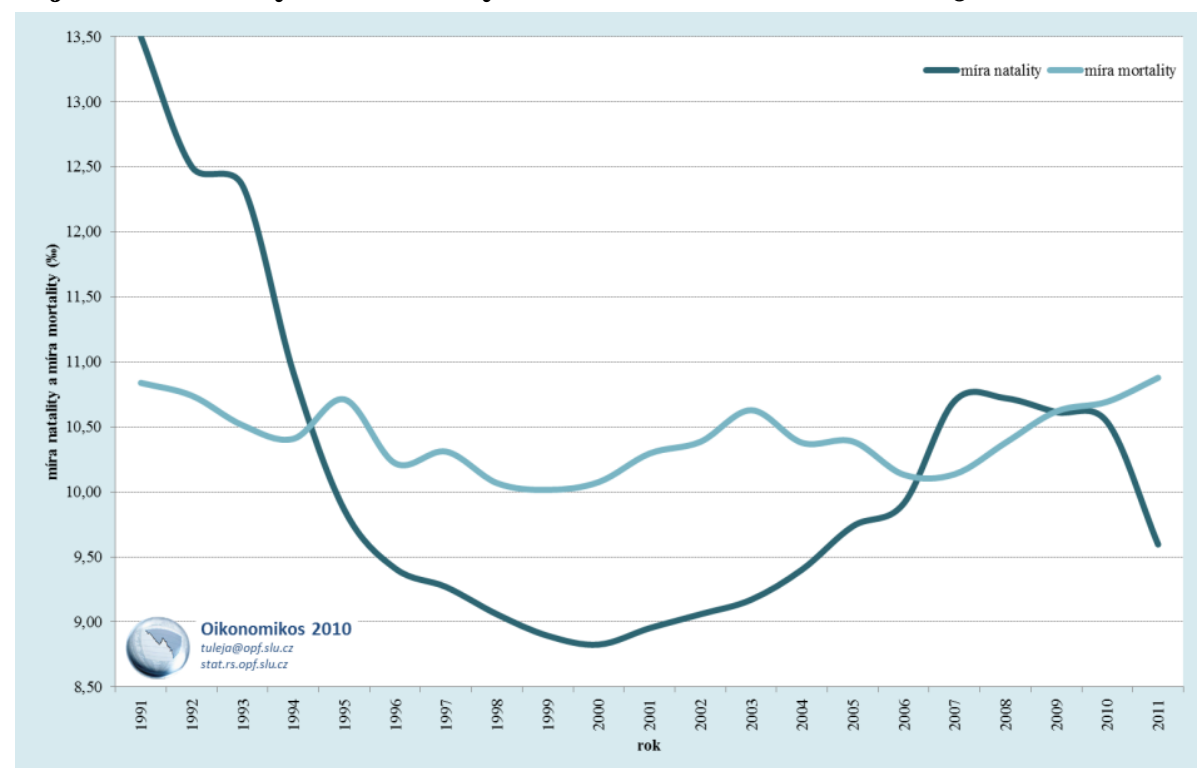

Zdroj: Vlastní výpočet na základě dat Českého statistického úřadu

Také u míry mortality můžeme v poslední dekádě 20. století zaznamenat téměř trvalý pokles hodnoty tohoto ukazatele, prričemž míra tohoto poklesu není tak výrazná jako v př́ípadě míry porodnosti. Tento pokles byl $\mathrm{v}$ následujících letech nejprve vystřídán pozvolným růstem počtu zemřelých osob na 1000 obyvatel a následně opětovným poklesem míry mortality, přičemž tento veskrze pozitivní vývoj byl zastaven v roce 2007, kdy na jeden tisíc obyvatel Moravskoslezského kraje připadlo 10,14 zemřelých. Od roku 2008 pak v kraji opět dochází $\mathrm{k}$ růstu hodnoty míry úmrtnosti, přičemž $\mathrm{v}$ roce 2011 dosáhla míra úmrtnosti v kraji hodnoty 10,88 \%o, což je nejvyšší hodnota tohoto ukazatele v Moravskoslezském kraji od roku 1991.

Jak je zřejmé z údajů zachycených v grafu 3 převyšovala míra porodnosti míru úmrtnosti pouze v letech 1991-1994 a v letech 2007 a 2008. Největší převis mortality nad natalitou pak můžeme zaznamenat $\mathrm{v}$ roce 2003, kdy míra úmrtnosti převyšovala míru porodnosti o 1,46 \%o, což v absolutním vyjádření znamená, že přirozený úbytek obyvatel Moravskoslezského kraje v daném roce dosáhl hodnoty 1830 obyvatel. Na základě výše uvedeného můžeme tedy konstatovat, že pokles přirozeného prŕrůstku obyvatelstva lze označit za jeden z významných faktorů úbytku obyvatel v Moravskoslezském kraji, přičemž pozitivní tendence, jež jsme zaznamenali v průběhu let 2007 a 2008, byly zejména v posledním roce námi analyzovaného období vystř́dány, již výše zmíněným výrazným propadem míry porodnosti, který se následně odrazil ve vývoji přirozeného přirůstku obyvatelstva, jehož hodnota $\mathrm{v}$ absolutním vyjádření dosáhla v daném roce výše -1 577 osob. 


\section{Migrace obyvatel Moravskoslezského kraje}

Na změnách struktury obyvatel Moravskoslezského kraje se však nepodílel pouze přirozený přírůstek, ale také vnitřní a vnější migrace obyvatelstva, přičemž tento faktor má na vývoj počtu obyvatel kraje značně negativní dopad. Jak lze vyčíst z údajů zachycených na graf 4 , jediným rokem, v jehož rámci můžeme v Moravskoslezském kraji zaznamenat kladný přírůstek stěhováním, byl rok 1992, kdy počet obyvatel přistěhovalých do Moravskoslezského kraje překročil počet obyvatel, kteří se z kraje vystěhovali o 218 osob. Ve všech ostatních letech námi sledovaného období pak můžeme zaznamenat pouze záporné migrační saldo, přičemž nejvýraznější převisy počtu vystěhovalých nad počtem přistěhovalých můžeme zaznamenat v posledních třech letech námi analyzovaného období, kdy čistá migrace dosáhla průměrné hodnoty $-3116,33$ osob.

\section{Graf 4: Celkový a přirozený přírůstek a přírůstek stěhováním v Moravskoslezském kraji v letech 1991-2011}

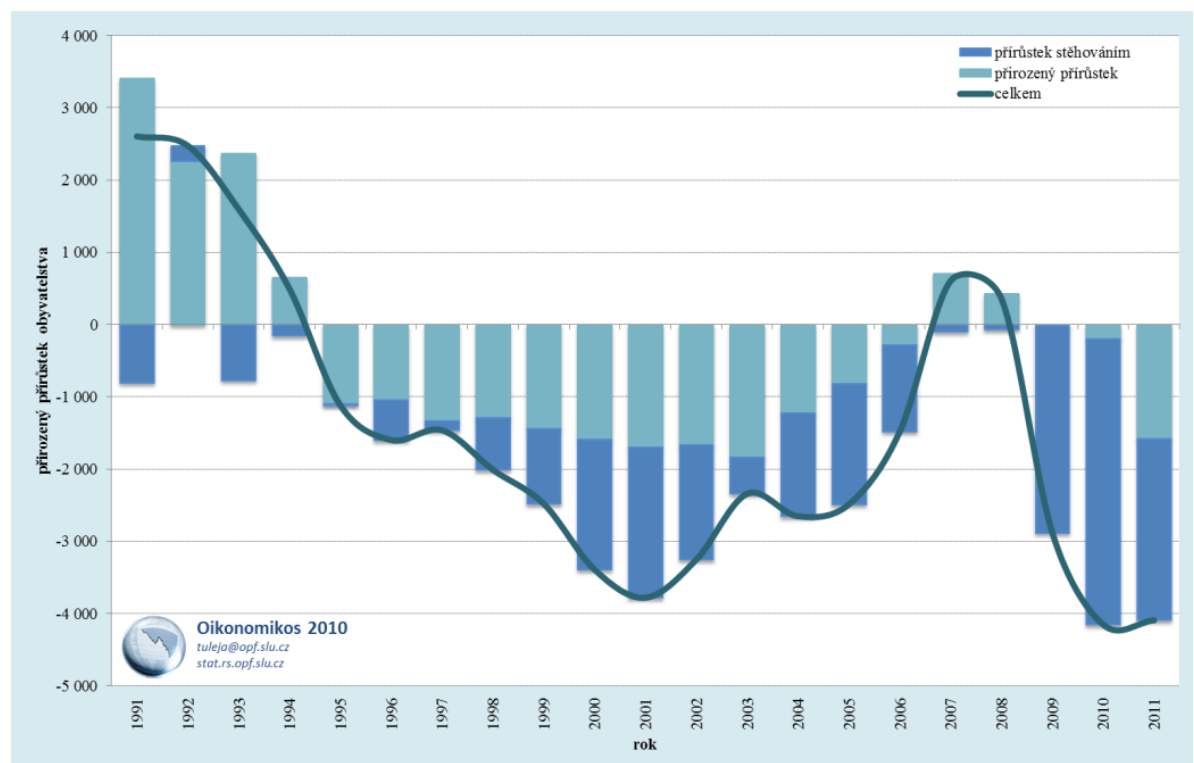

Zdroj: Vlastní zpracování na základě dat z Českého statistického úřadu

Porovnáme-li vliv přirozeného př́růstku a přirůstku stěhováním na celkový růst počtu obyvatel Moravskoslezského kraje, pak musíme konstatovat, že z dlouhodobého hlediska se na celkovém přírůstku obyvatelstva mnohem výrazněji podílí přirozený přírůstek, o čemž svědčí také údaje z let 1991 až 2011, kdy podíl tohoto ukazatele na celkovém prrírůstku obyvatel Moravskoslezského kraje dosahoval výše 70,22 \%. Pokud bychom toto časové období zkrátili pouze na první dekádu nového tisíciletí, pak zjistíme, že v kraji dochází $\mathrm{k}$ poměrně zásadnímu zvratu, $\mathrm{v}$ jehož důsledku vliv přirozeného přírůstku na celkový růst obyvatelstva klesá. V letech 2000-2011 tak podíl tohoto indikátoru na celkovém prírůstku dosahoval již pouhých 49,81 \% a v posledních třech letech sledovaného období dokonce poklesl na necelých patnáct procent $(14,48 \%)$. Na základě výše řečeného můžeme tedy konstatovat, že především v posledních jedenácti letech se rozhodujícím prvkem demografického vývoje v Moravskoslezském kraji začíná stávat migrační saldo, jež dlouhodobě dosahuje záporných hodnot. Vysoké hodnoty obratu migrace, které jsou patrné i z grafu 6, tak z kraje činí, ve srovnání s ostatními kraji České republiky, region s relativně nestabilizovaným obyvatelstvem.

Při podrobnější analýze př́růstku stěhováním dospějeme k závěru, že výrazně negativní vliv na migrační saldo Moravskoslezského kraje má vnitřní stěhování v rámci České republiky. 
Vyjdeme-li z dostupných statistických údajů, pak dospějeme k závěru, že v období vymezeném roky 1992 a 2011 se z Moravskoslezského kraje do ostatních krajů České republiky vystěhovalo v průměru o 2634,67 osob více, než se do kraje přistěhovalo. Díky tomu se vnitřní migrační saldo podílelo na celkovém př́růstku stěhováním -159,62 \% . V průběhu sledovaného období se v Moravskoslezském kraji navíc prosazovaly spíše tendence k prohlubování záporného salda vnitřní migrace, když v prvních pěti letech (19921996) dosáhl úbytek obyvatel vnitřním stěhováním souhrnné výše 5529 osob, v letech 199720019495 osob, v třetím pětiletém období (2002-2006) 12408 osob a v posledním časovém úseku ohraničeném roky 2007 a 2011 dokonce 14604 osob.

Graf 5: Př́růiostek stěhováním dle způsobu imigrace z Moravskoslezského kraje v letech 1992-2011

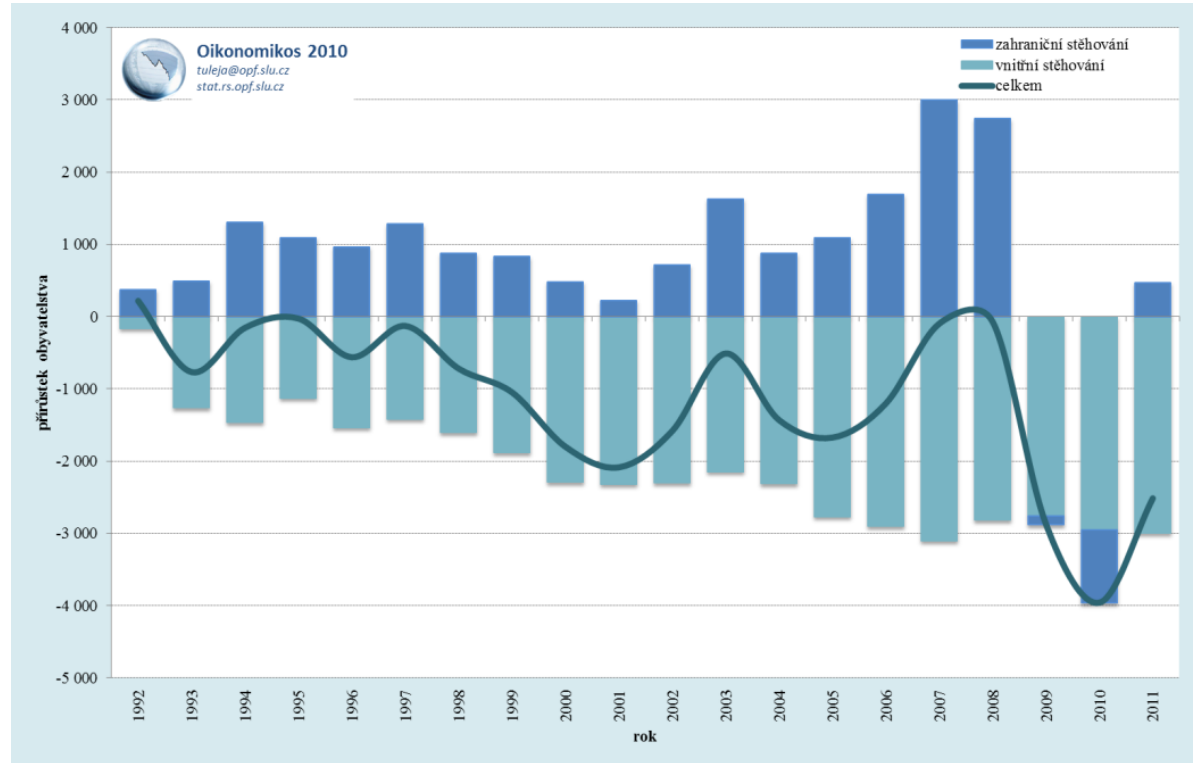

Zdroj: Vlastní zpracování na základě dat z Českého statistického úřadu

Poněkud odlišný trend pak můžeme zaznamenat u přírůstku stěhováním ze zahraničí, kde se v průběhu let 1992 až 2011 prosazovaly spíše tendence k mírnému nárůstu hodnoty tohoto ukazatele. $\mathrm{V}$ průběhu celého sledovaného období bylo $\mathrm{v}$ př́padě zahraničního stěhování pro Moravskoslezský kraj, s drobnou výjimkou v letech 2009 a 2010, charakteristické kladné migrační saldo, které dosahovalo průměrné výše 984,08 osob, což je hodnota, která nebyla schopna pokrýt úbytek obyvatelstva, $\mathrm{k}$ němuž $\mathrm{v}$ regionu docházelo $\mathrm{v}$ důsledku vnitrorepublikové migrace. S nejvýraznější přistěhovaleckou vlnou se ve sledovaném regionu můžeme setkat v období vrcholící hospodářské konjunktury v České republice, tj. v letech 2006 až 2008, kdy čistá zahraniční migrace dosáhla souhrnné výše 7435 osob. Pokud bychom se opět zaměřili na již dříve vymezené pětileté bloky, pak můžeme konstatovat, že k největšímu kumulovanému prírůstku obyvatel zahraničním stěhováním došlo v letech 2002 až 2006, kdy se hodnota tohoto indikátoru pohybovala na úrovni 6005 osob, a následně pak v letech 2007 až 2011, kde i přes pokles zahraniční migrace v letech 2009 a 2010, můžeme zaznamenat souhrnný čistý prrírůstek obyvatel zahraničním stěhováním na úrovni 5 tis. osob. Naopak obdobím, jež se vyznačujeme nejslabší vlnou zahraniční imigrace do Moravskoslezského kraje je časový úsek vymezený roky 1997 a 2001, kdy souhrnný počet nově prŕíchozích ze zahraničí prrekročil souhrnný počet osob odcházejících do zahraničí o „pouhých“ 3712 obyvatel. 
Z hlediska jednotlivých věkových kategorií vykazovalo v letech 1991-2010 nejvýraznější výkyvy migrace obyvatelstvo v produktivním věku, tj. mezi patnácti a šedesáti čtyřmi lety. Naopak nejstabilnější vývoj můžeme v tomto časovém úseku zaznamenat u obyvatel starších 65-ti let, tj. u věkové kategorie, která již, vzhledem ke svému vysokému věku, z větší části necítí potřebu stěhovat se. Jak je z grafu 6 zřejmé, po relativně stabilní vývoji v první polovině devadesátých let, došlo v Moravskoslezském kraji k prvnímu výraznějšímu odlivu obyvatel v produktivním věku mezi roky 1997 a 2001, kdy kumulovaná hodnota prírůstku stěhováním obyvatel ve věkové kategorii od 15 do 64 let dosáhla hodnoty -4712 osob. Na tento výrazný odliv produktivního obyvatelstva navázalo dvouleté období zpomalování odchodu obyvatel spadajících do této věkové kategorie, jež bylo následně opět vystřídáno krátkodobým zrychlením (2004-2005) a krátkodobým zpomalením, resp. dvouletým kladným migračním saldem (2006 a 2007-2008). S druhou výraznou vlnou čisté emigrace obyvatel v produktivním věku se pak $\mathrm{v}$ Moravskoslezském kraji setkáváme na konci námi analyzovaného období, kdy se z námi sledovaného regionu v průběhu dvou let vystěhovalo více než šest tisíc obyvatel v produktivním věku (6 056 osob).

\section{Graf 6: Přírůstek stěhováním celkem a dle věku v Moravskoslezském kraji v letech 1991-2010}
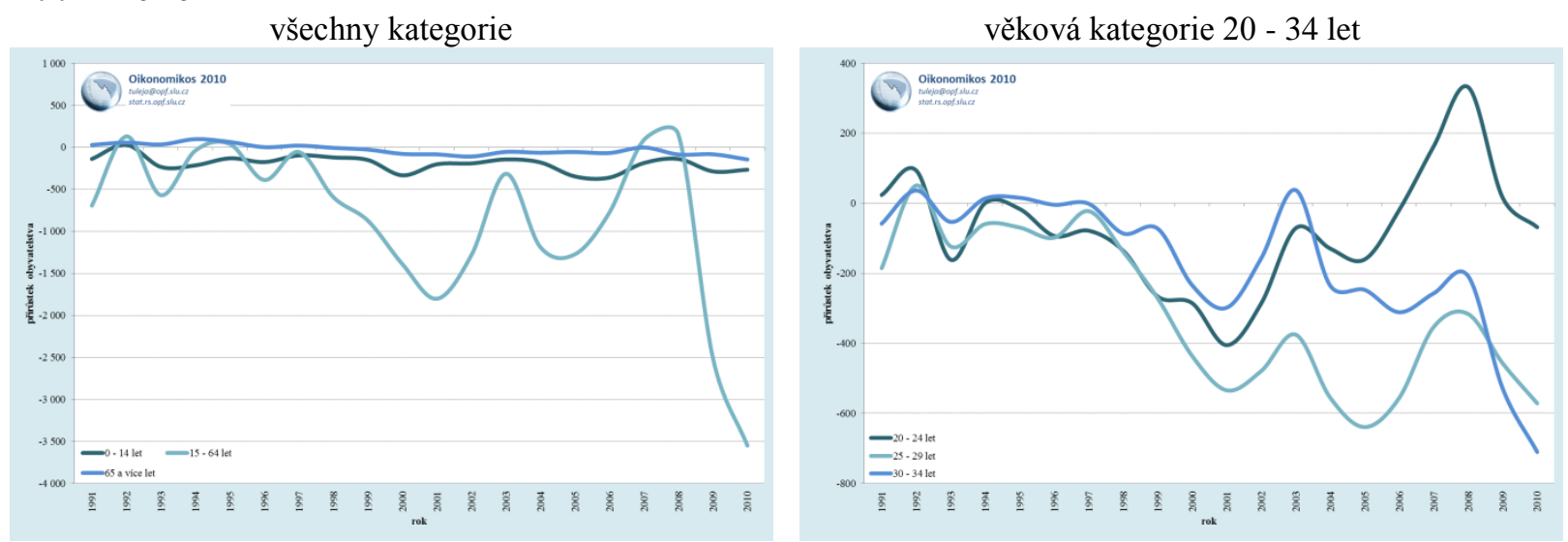

Zdroj: Vlastní zpracování na základě dat z Českého statistického úřadu

Jak je z výše uvedeného zřejmé, určitou výjimkou v dlouhodobém trendu vývoje prrírůstku stěhováním obyvatel v produktivním věku byly roky 2007 a 2008, kdy migrační saldo obyvatel Moravskoslezského kraje nabývalo kladných hodnot. Budeme-li pátrat po příčinách tohoto krátkodobého pozitivního obratu, pak je nalezneme zejména ve zlepšení situace na trhu práce, $\mathrm{v}$ jehož rámci došlo $\mathrm{k}$ navýšení nabídky volných pracovních příležitostí, o čemž svědčí také vývoj ukazatele počet uchazečů o práci na jedno volné pracovní místo (viz graf 7). Tento vývoj pak byl spojen především s rozvojem zpracovatelského průmyslu a vstupem nových investorů do jednotlivých průmyslových zón nacházejících se na území kraje. Konkrétně se pak jednalo o vstup společností:

- Behr Ostrava Czech, s. r. o., PLAKOR CZECH, s. r. o. a CROMODORA WHEELS s. r. o. do průmyslové zóny Mošnov,

- Brose CZ spol. s r. o., Rieger Automotive International, a. s., DURA Automotive Systems CZ, s. r. o. a Erich Jaeger, s. r. o. do průmyslového parku Kopřivnice

- a zejména pak společností Hyundai Motor Manufacturing Czech s. r. o., Mobis Automotive Czech, s. r. o. a Dymos Czech Republic, s. r. o. do průmyslové zóny Nošovice. 


\section{Graf 7: Počet uchazečů o práci na jedno volné pracovní místo v Moravskoslezském kraji v letech 2000-2011}

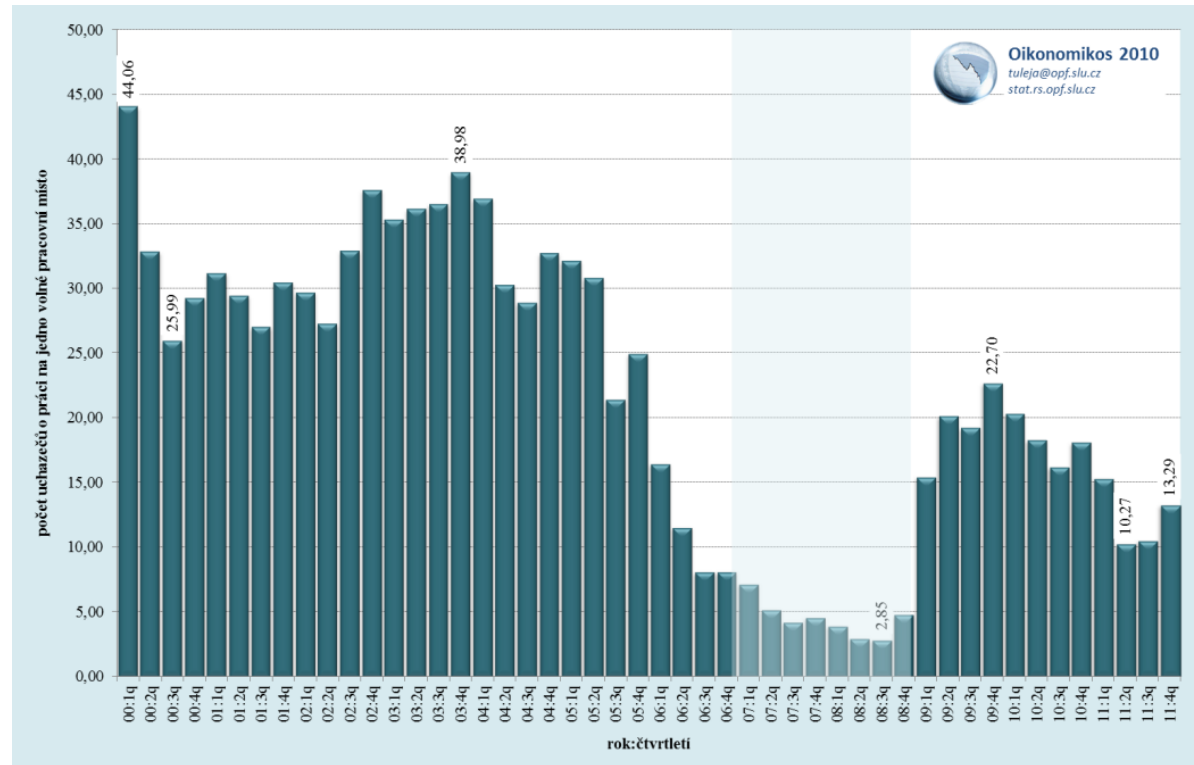

Zdroj: Vlastní výpočet na základě dat Ministerstva práce a sociálních věci České republiky

Budeme-li podrobněji analyzovat př́růstek stěhováním ve věkové kategorii od 14 do 64 let věku, pak zjistíme, že nejvýraznější absolutní pokles byl v námi analyzovaném období zaznamenán u věkové kategorie 25 až 29 let, a to 6185 osob. Jak je patné z grafu 8, $\mathrm{k}$ dlouhodobému poklesu záporného migračním saldem u této kategorie dochází v podstatě od roku 1997, přičemž k nejvýraznějšímu odlivu došlo v letech 1998 až 2001. Podobný vývoj pak můžeme zaznamenat také u věkové kategorie 30-34 let. Také v tomto př́ípadě dochází $\mathrm{k}$ prvnímu výraznějšímu odliv obyvatel na přelomu tisíciletí, přičemž na rozdíl od předchozí věkové kategorie, nemá tento propad trvalý charakter, když v roce 2003 u této věkové kategorie dochází $\mathrm{k}$ čistému přírůstku stěhováním. Po tomto krátkodobém zlepšení dochází $\mathrm{v}$ následujících sedmi letech $\mathrm{v}$ Moravskoslezském kraji $\mathrm{v}$ této věkové kategorii opět k prohlubování odlivu obyvatel, přičemž tento propad vyvrcholil v posledních dvou letech námi sledovaného období, kdy prrírůstek stěhováním dosáhl hodnoty -1 239 osob, díky čemuž se tato věková kategorie, $\mathrm{z}$ hlediska odlivu obyvatel $\mathrm{v}$ produktivním věku, zařadila v Moravskoslezském kraji na první místo pomyslného žebříčku, a to před věkovou kategorií 25-29 let (-1 028 osob) a 35-39 let (-1 001 obyvatel). Z výše uvedeného je tedy zřejmé, že Moravskoslezský kraj nejčastěji opouštějí lidé ve věkové kategorii od 25 do 40 let, u nichž se dá předpokládat, že jejich rozhodnutí o vystěhování z kraje poměrně úzce souvisí s hledáním odpovídajícího pracovního místa, a to bez ohledu na to, zda při přijetí tohoto rozhodnutí hrají rozhodující roli lepši finanční podmínky, nebo větší jistota udržení si pracovního místa.

Za poměrně zajímavý můžeme označit také vývoj migračního salda $\mathrm{v}$ jednotlivých okresech Moravskoslezského kraje. Jak je zřejmé i z údajů zachycených v grafu 8, jediným okresem, jenž se v námi sledovaném kraji dlouhodobě vyznačuje kladným migračním saldem, je okres Frýdek-Místek, kde v průběhu jednadvaceti let vzrostl v důsledku migrace počet obyvatel o 5320 osob. Naopak okresy s největším úbytkem obyvatel jsou okresy Ostrava-město, kde mezi roky 1991 až 2011 poklesl v důsledku stěhování počet obyvatel o téměř 13 tisíc a Karviná, v jejímž př́padě byl pokles obyvatelstva o něco nižší, když finální hodnota kumulovaného přírůstku stěhováním v tomto př́ípadě dosáhla výše -11791 osob. Ze zbývajících tří okresů můžeme za poněkud kritičtější označit také odliv obyvatel z okresu Bruntál, $v$ jehož př́padě dosáhlo čisté migrační saldo hodnoty -4017 obyvatel. V okresech 
Nový Jičín a Opava se dlouhodobé kumulované saldo pohybovalo na úrovni -83 a -237 osob, $\mathrm{z}$ čehož se dá usuzovat, že $\mathrm{v}$ príípadě těchto okresů počet obyvatel, kteří se $\mathrm{z}$ daného okresu vystěhují, mírně převyšuje počet osob, které si daný okres vyberou za místo svého trvalého pobytu.

\section{Graf 8: Přrírůstek stěhováním obyvatel $\mathrm{v}$ jednotlivých okresech Moravskoslezského kraje v letech 1991-2011}

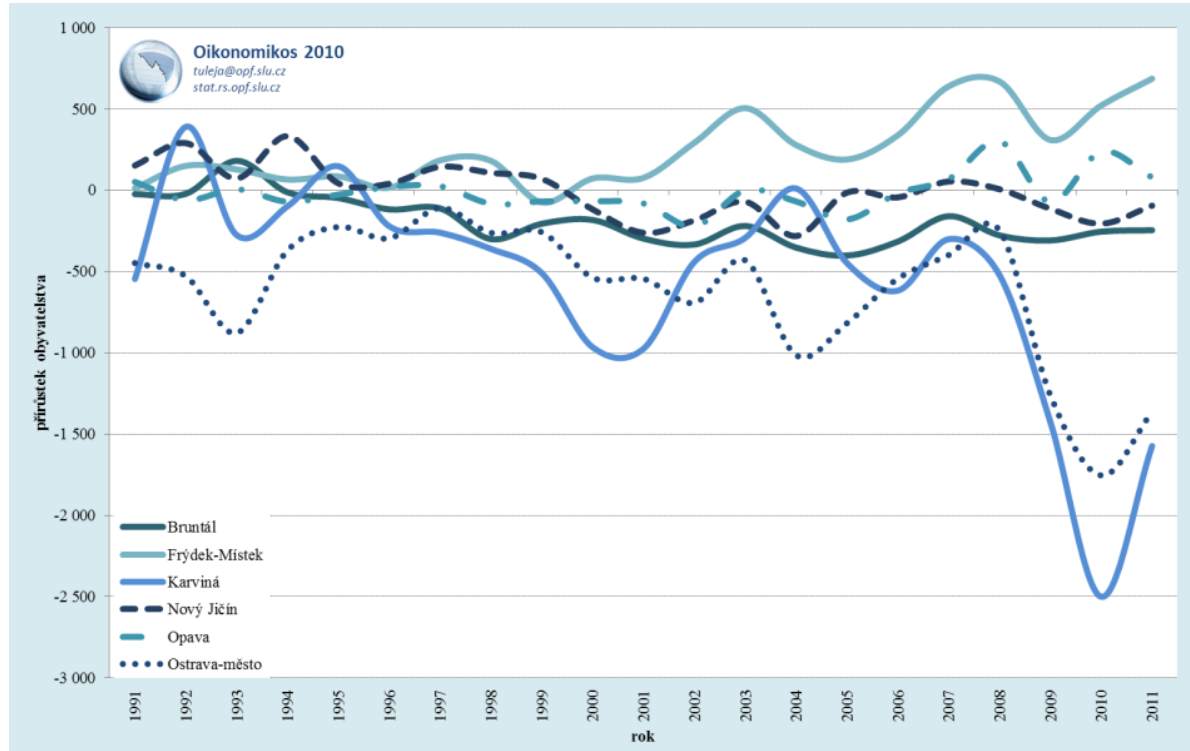

Zdroj: Vlastní výpočet na základě dat Českého statistického úřadu

\section{Závěr}

V posledních jednadvaceti letech se počet obyvatel Moravskoslezského kraje snížil o více než 50 tisíc osob a tento region tak s 1230,5 tis. obyvateli ztratil pozici nejlidnatějšího kraje České republiky, která v posledních letech připadla Středočeskému kraji, přičemž z hlediska počtu obyvatel byl MS-kraj také předstižen H1. m. Prahou. Podíváme-li se na demografický vývoj v Moravskoslezském kraji poněkud podrobněji, pak dospějeme k závěru, že po krátkodobém mírném růstu, či spíše stagnaci obyvatelstva, k níž docházelo v první polovině 90. let (1992-1994), se v námi analyzovaném regionu začal prosazovat trend poklesu počtu obyvatel žijících na území kraje, přičemž drobnou výjimkou v tomto vývoji byly roky 2007 a 2008, kdy počet obyvatel žijících na území Moravskoslezského kraje v podstatě stagnoval. S úbytkem obyvatel se kromě kraje potýkaly také jednotlivé okresy, a to s jednou jedinou výjimkou, již byl okres Frýdek-Místek, který v letech 1991 až 2011 zaznamenal celkový př́růstek počtu obyvatel o 1197 osob. Naopak nejvíce se na poklesu obyvatelstva kraje podílely okresy Karviná a Ostrava-město.

Podobně jako v celé České republice, také v Moravskoslezském kraji se na poklesu počtu obyvatel výrazně podepsal pokles intenzity plodnosti, když se počet živě narozených dětí, připadající na jednu ženu snížil z hodnoty 1,68 v roce 1993 na hodnotu 1,47 v roce 2010, díky čemuž se Moravskoslezský kraj zařadil mezi pětici krajů s nejnižší úrovní úhrnné plodnosti v České republice. Vývoj úhrnné plodnosti se následně podepsal také na vývoji přirozeného př́růstku obyvatel kraje. Tento byl ovlivněn zejména intenzivním poklesem míry natality, která v průběhu jednadvaceti let snížila z 13,50 na 9,60 \%o, a to v situaci, kdy míra mortality ve své podstatě stagnovala $(10,84$ a $10,88 \%$ ). 
Za mnohem závažnější problém, než je pokles přirozeného přírůstku obyvatel kraje, pak můžeme označit záporné migrační saldo, s nímž se Moravskoslezský kraj potýkal, s drobnou výjimkou v roce 1992, v celém námi sledovaném období. $Z$ dostupných údajů je pak zřejmé, že výrazně nepříznivý vliv na migrační saldo Moravskoslezského kraje má vnitřní stěhování, které se na celkovém přírůstku migrací podílelo $-159,62 \%$. Naopak u přírůstku stěhováním ze zahraničí jsme mohli v daném období zaznamenat spíše tendence $\mathrm{k}$ mírnému růstu. Z hlediska jednotlivých věkových kategorií pak za poměrně kritickou považujeme situaci u skupiny obyvatel ve věku od 25 do 39 let, v jejímž príípadě dlouhodobě zaznamenáváme poměrně vysoká záporná migrační salda, což se negativně odráží nejen v oblasti migrace obyvatel, ale $\mathrm{s}$ největší pravděpodobností také v oblasti natality.

\section{Literatura:}

[1] ČSÚ Demografická ročenka krajů 2000 až 2009. [online]. Praha: ČSÚ, 2012. [cit. 27.5.2012]. Dostupné z: http://www.czso.cz/csu/2010edicniplan.nsf/publ/4027-10-.

[2] ČSÚ Demografická ročenka krajů 2001 až 2010. [online]. Praha: ČSÚ, 2012. [cit. 27.5.2012]. Dostupné z: http://www.czso.cz/csu/2011edicniplan.nsf/publ/4027-11-r_2011.

[3] ČSÚ Migrace obyvatel Moravskoslezského kraje z dlouhodobějšiho pohledu. [online]. Praha: ČSÚ, 2012. [cit. 27.5.2012]. Dostupné z: http://www.czso.cz/xt/redakce.nsf/i/migrace_obyvatel_moravskoslezskeho_kraje_z_dlouh odobejsiho_pohledu.

[4] KOLEKTIV AUTORŮ Situační analýza Jihomoravského kraje. [online]. Brno: MU, 2006. [cit. 27.5.2012]. Dostupné z: http://www.krjihomoravsky.cz/Default.aspx?pubid=22723...7 ...7.

[5] KOSCHIN, F. A KOL. Prognóza lidského kapitálu obyvatelstva České republiky do roku 2050. Praha: Oeconomica, 2007. 105 s.

[6] MPSV Statistika nezaměstnanosti. [online]. Praha: MPSV, 2011. [cit. 9.6.2012]. Dostupné z: http://portal.mpsv.cz/sz/stat/nz.

[7] ŽÁK, M. A KOL. Velká ekonomická encyklopedie. 2. rozšǐrené vydání. Praha: Linde, 2002. ISBN 80-7201-381-5.

\section{JEL J61, J11, J16}

\section{doc. Ing. Pavel Tuleja, Ph.D.}

katedra ekonomie

Obchodně podnikatelská fakulta v Karviné

Slezská univerzita v Opavě

Univerzitní náměstí 1934/3, 73340 Karviná

Tel.: +420 596398259

tuleja@opf.slu.cz

\section{Ing. Karin Gajdová}

katedra ekonomie

Obchodně podnikatelská fakulta v Karviné

Slezská univerzita v Opavě

Univerzitní náměstí 1934/3, 73340 Karviná

Tel.: +420 596398346

gajdova@opf.slu.cz 